\title{
MENINGKATKAN KOMPETENSI GURU DALAM MENYUSUN LEMBAR KERJA SISWA MELALUI WORKSHOP DI GUGUS SEKOLAH
}

\author{
Lilis Kustriani ${ }^{\text {a) }}$ \\ ${ }^{a)}$ SD Negeri Kampung Sawah, Bogor, Indonesia \\ e-mail korespondensi : liliskustriani2015@gmain.com
}

diterima: 29 Januari 2019; direvisi: 16 Februari 2019; disetujui: 26 Februari 2019

\begin{abstract}
This research is a School Action Research (SAR) conducted at primary school (SD Negeri Kampung Sawah) in Bogor Utara District at Semester 2 of the 2017-2018 Academic Year. The research was conducted in two cycles, each cycle consisting of four stages, namely: planning, implementation, observation and reflection. The specified performance indicator is when a minimum score of 12 (quite active). In compiling the Student Worksheet it can be said to be successful. The aspects measured in the observation are the enthusiasm of the teacher, interaction with the teacher in the teacher's work group, group cooperation, activities in group discussion. The analysis found that there was an increase in teacher activity and competence in preparing the Student Worksheet from cycle I to cycle II. Achievement of performance indicators is in action II. Thus, it can be said that cluster activities can improve the competence of teachers in Kampung Sawah State Primary School, North Bogor District, Bogor City Semester 2 2017-2018 Academic Year. The teacher gave a positive response to the results of the workshop in the Cluster. The results showed that the preparation of Student Worksheets could improve the competence of teachers in Kampung Sawah Public Elementary Schools. Thus it can be suggested to supervisors, friends or other researchers to use cluster activities as a forum to improve teacher competencies that are carried out continuously. Cluster activities can increase the competence of public elementary school teachers in preparing student worksheets..
\end{abstract}

Keywords: cluster workshop, student worksheets, teacher competencies.

\section{PENDAHULUAN}

Pendidikan adalah faktor yang paling penting dan prioritas utama yang membutuh-kan perhatian serius dari semua pihak, karena pendidikan adalah penentu kemajuan bangsa di masa depan [1] . Tujuan dan cita-cita nasional, untuk kehidupan intelektual bangsa terkandung dalam UUD 1945. Pemerintah bersama masyarakat terus mencari pengembangan pendidikan demi terwujudnya bangsa yang mandiri, unggul dan siap menghadapi dunia globalisasi [2]. Dunia pendidikan dewasa ini banyak ditemukan berbagai masalah seperti permasalahan merosotnya karakter peserta didik. Hal ini menandakan bahwa karakter generasi muda saat ini sudah mulai rusak dan belum adanya pula penanganan secara tuntas mengenai permasalahan ini. Salah satu cara untuk meminimalisasi peristiwa-peristiwa tersebut ialah melalui penerapan pendidikan karakter. Salah satu hal yang sangat mendukung kemajuan pendidikan karakter yaitu melalui budaya sekolah. Budaya sekolah yang diprogramkan dengan baik akan mendukung tingkat keberhasilan dari program pendidikan karakter.

Kepala sekolah sangat memegang peranan yang sangat penting dalam menentukan keberhasilan sekolah. Dalam Permendiknas Nomor 13 Tahun 2007 tentang kompetensi Kepala Sekolah dinyatakan bahwa seorang kepala sekolah harus memiliki kompetensi kepribadian, manajerial, kewirausahaan, supervisi dan sosial. Salah satu kompetensi kepala sekolah yang harus dilaksanakan yaitu untuk mengelola dan memotivasi guru-guru dalam melaksanakan tugasnya sebagai pelaksana proses pembelajaran di kelas.

Kompetensi professional guru merupakan kompetensi yang menggambarkan kemampuan khusus yang sadar dan terarah kepada tujuan-tujuan tertentu, diantaranya dengn mengembangkan materi pembelajaran yang ditempuh secara kreatif. Salah satu kompetensi profesional guru yaitu terampil dalam menyajikan proses pembelajaran di kelas. Dalam menyajikan proses pembelajaran di kelas guru senantiasa memberikan Lembar kerja Siswa sebagai salah satu media dalam pembelajaran. Melalui Lembar Kerja Siswa diharapkan siswa dapat belajar bersama, berdiskusi dengan teman di kelasnya untuk dapat menemukan konsep pembelajaran yang akan dan sedang dipelajari.

Namun Lembar Kerja Siswa yang digunakan guru umumnya Lembar Kerja yang sudah jadi yang berasal dari penerbit yang berupa lembar soal-soal yang harus diisi siswa. Bukan Lembar Kerja yang dibuat guru yang harus dikerjakan siswa agar siswa memahami konsep mata pelajaran yang sedang dan akan dipelajari. Sedangkan saat ini guru dituntut untuk dapat membuat sendiri Lembar Kerja Siswa.

Dari 12 orang guru yang ada di SD.Negeri Kampung Sawah hanya ada 3 orang guru ( $25 \%$ ) yang membuat Lembar Kerja Siswa, itupun masih tercantum dalam Rencana Pelaksanaan Pembelajaran (RPP), tidak dibuat tersendiri. Karena Lembar Kerja Siswa cukup penting dan dapat meningkatkan aktivitas belajar siswa, maka guru ditugaskan untuk membuat Lembar Kerja Siswa secara tersendiri ,tidak yang tercantum dalam RPP.

Penelitian Tindakan Sekolah ini diawali rendahnya kompetensi guru SD Negeri Kampung Sawah Kecamatan Bogor Utara Kota Bogor dalam menyusun lembar kerja siswa. Oleh karena itu kepala sekolah akan melakukan penelitian tindakan sekolah ini melalui Workshop di gugus sekolah dengan harapan semua guru menguasai kompetensi 
khususnya tentang menyusun lembar kerja siswa. Tujuan penelitian ini adalah : 1 . Untuk menngetahui workshop di gugus sekolah dapat meningkatkan kompetensi guru dalam mmenyusun lembar kerja siswa di SD Negeri Kampung Sawah Kecamatan Bogor Utara Kota Bogor semester 2 tahun pelajaran 2017-2018. 2. Untuk mendeskripsikan proses peningkatan kompetensi guru sebelum dan sesudah menggunakan workshop di gugus sekolah dalam menyusun lembar kerja siswa di SD Negeri Kampung Sawah Kecamatan Bogor Utara Kota Bogor semester 2 tahun pelajaran 2017-2018. 3. Untuk menngukur berapa besar peningkatan kompetensi guru sesudah menggunakan Workshop di gugus sekolah dalam mengembangkan penyusunan lembar kerja siswa di SD Negeri Kampung Sawah Kecamatan Bogor Utara Kota Bogor semester 2 tahun pelajaran 2017-2018

\section{Kompetensi Guru}

Guru merupakan tenaga pendidik yang profesional dibidangnya, dibuktikan dengan kemampuan akademik berupa sertifikat atau ijazah pendidik. Sejalan dengan ungkapan Payong [3] dimana kualifikasi bersifat statis, artinya pengakuan terhadap kemampuan akademik seseorang yang dibuktikan dengan pemberian ijazah atau sertifikat tidak berubah sejauh bersangkutan menyandang gelar akademik yang sesuai. Hal ini menunjukkan bahwa dengan dibuktikan ijazah atau sertifkat pendidik maka dianggap telah menguasai kompetensi sebagai seorang guru. Untuk menjadi guru yang profesional, guru harus menjadi otoritas mutu dan profesionalisme guru sebagai etos kerja mereka dan menjadikannya sebagai landasan orientasi berperilaku dalam tugas-tugasnya profesinya (Karsidi [4]). Sehingga, guru yang profesional apabila sesuai dengan profesi yang diperoleh dan mengajarkan kompetensikompetensi yang dimiliki. Tugas dan tanggung jawab tersebut erat kaitannya dengan kemampuan-kemampuan yang disyaratkan untuk memangku profesi tersebut. Kemampuan dasar tersebut tidak lain adalah kompetensi guru" (Saud, [5]).

Guru dikatakan kompetensi di bidangnya apabila memiliki memapuan secara pengetahuan, keterampilan dan sikap. Boyatzis [6] menyatakan bahwa "a competency defined as capability or ability" yang berarti kemampuan atau kecakapan. Diperjelas oleh Mission [7] bahwa "competency is a combination of knowledge, skill, and attitude". Pernyataan tersebut mengandung makna bahwa kompetensi merupakan kombinasi antara pengetahuan, keterampilan dan sikap. Sedangkan Lynn dan Nixon [8] menjelaskan "competencies may range from recall and understanding of fact and concepts, to advanced motor skill, to teaching behaviors, and professional values". Artinya kompetensi terdiri dari pengalaman dan pemahaman tentang fakta dan konsep, peningkatan kehlian, pengajaran perilaku dan sikap. Dapat disimpulkan bahwa kompetensi merupakan kemampuan keahlian pada bidang tertentu yang diperoleh berdasarkan pengalaman yang dapat diwujudkan berupa pengetahuan, keterampilan dan sikap.

\section{Lembar Kegiatan Siswa}

Lembar Kegiatan Siswa (LKS) adalah paduan siswa yang digunakan untuk melakukan kegiatan penyelidikan atau pemecahan masalah. (Trianto, [9]). Lembar kegiatan siswa dapat berupa panduan untuk latihan pengem-bangan aspek kognitif maupun panduan untuk pengembangan semua aspek pembelajaran dalam bentuk panduan eksperimen atau demonstrasi.

LKS menjadi sumber belajar dan media pembelajaran tergantung pada kegiatan pembelajaran yang dirancang. Penggunaan media memberikan manfaat dalam proses pembelajaran, hal ini dikemukakan oleh Arsyad [10] antara lain yaitu : (1) Media pembelajaran dapat memperjelas penyajian pesan dan informasi sehingga proses belajar semakin lancar dan meningkatkan hasil belajar. (2)Media pembelajaran dapat meningkatkan motivasi siswa, dengan mengarahkan perhatian siswa sehingga memung-kinkan siswa belajar sendiri-sendiri sesuai kemampuan dan minatnya. (3) Media pembelajaran dapat mengatasi keterbatasan indera, ruang, dan waktu. (4) Media pembelajaran dapat memberikan kesamaan pengalaman kepada siswa tentang peristiwa-peristiwa di lingkungn mereka, serta memungkinkn terjadinya interaksi langsung dengan guru, masyarakat, dan lingkungannya. LKS sebagai sumber belajar dapat digunakan sebagai alternatif media pembelajaran. LKS termasuk media cetak hasil pengembangan teknologi cetak yang berupa buku dan berisi materi visual, seperti yang diungkapkan oleh Arsyad [10]. LKS merupakan jenis hand out yang dimaksudkan untuk membantu siswa belajar secara terarah. Menurut Slameto [11] pembelajaran dipengaruhi oleh dua faktor yaitu faktor internal berupa kemampuan awal siswa dan faktor eksternal berupa pendekatan pembelajaran. Pendekatan pembelajaran dapat dilakukan dengan menggunakan media LKS. ada dua yang perlu diperhatikan pada saat mendesain LKS, yaitu tingkat kemampuan membaca peserta didik dan pengetahuan peserta didik. LKS didesain untuk digunakan peserta didik secara mandiri. Artinya, guru sebagai pendidik hanya berperan sebagai fasilitator, dan peserta didiklah yang diharapkan berperan secara aktif dalam mempelajari materi yang terdapat di dalam LKS.

\section{Kelompok Kerja Guru (Gugus)}

Pertemuan guru guru melalui Kelompok Kerja Guru (KKG) sebagai wadah pembinaan dalam peningkatan kemampuan profesional guru merupakan bagian dari rangkaian kegiatan supervisi yang dilakukan oleh pengawas dan kepala sekolah sebagai seorang supervisor. Dalam wadah ini supervisor melakukan bimbingan, pengawasan serta pembinaan terhadap kegiatan guru sehingga guru mampu mengembangkan kualitas profesionalnya secara optimal yang pada akhirnya akan memperbaiki mutu pengajaran.

Partisipasi guru dalam KKG merupakan bentuk keikutsertaan guru dalam rangka peningkatan kompetensinya. Pertemuan-pertemuan dalam kelompok kerja sebagai satu upaya efektif untuk melakukan pembinaan profesional. Wadah kegiatan guru ini pada dasarnya 
bertujuan merespon perkembangan ilmu pengetahuan dan teknologi yang menuntut penyesuaian dan pengembangan profesional guru. Melalui wadah ini para guru berkomunikasi, berkonsultasi, dan saling berbagi informasi serta pengalaman.

KKG pada gugus sekolah terdiri atas semua guru yang unit kerjanya berada dalam satu administrasi gugus. Gugus sekolah itu sendiri merupakan gabungan atau sinergi dari beberapa sekolah yang berada dalam lingkungan terdekat, salah satu sekolah yang paling lengkap fasilitasnya bertindak sebagai SD inti, sedangkan SD yang lainnya sebagai SD imbas. Hal ini sesuai dengan pernyataan Bafadal [12] bahwa gugus sekolah dasar merupakan kumpulan dari beberapa sekolah (3-8 sekolah) yang berdekatan dimana guru, kepala sekolah, dan pengawas sekolah dapat melakukan kegiatan-kegiatan secara bersama-sama untuk mengatasi masalah yang berkaitan dengan pelaksanaan pendidikan.

Pengetahuan, keterampilan dan kecakapan manusia dikembangkan melalui belajar. Banyak cara yang dapat dilakukan untuk memperoleh ketiga aspek tersebut seperti belajar di dalam sekolah, di luar sekolah, tempat bekerja, sewaktu bekerja, melalui pengalaman dan melalui workshop. Menurut Brooks-Harris, Jeff E [13], "A workshop is a shortterm learning experience that encourages active, experiential learning and uses a variety of learning activities to meet the needs of diverse learners". Artinya, Workshop adalah pengalaman belajar dalam waktu singkat yang mendorong belajar aktiv, belajar dalam nuansa ikut mengalami dan menggunakan aktivitas belajar yang bervariasi sehingga memenuhi kebutuhan peserta yang beragam.

\section{METODE PENELITIAN}

Metode penelitian yang digunakan dalam penelitian ini adalah Deskriptif Analitik melalui Penelitian Tindakan Sekolah, yaitu studi yang digunakan untuk mengumpulkan data, mendeskripsikan, mengolah, menganalisa, dan menafsirkan data sehingga memperoleh gambaran yang sistematis

Metode penelitian deskritif analisis digunakan untuk mengetahui permasalahan dengan cara menguraikan secara rinci dan jelas, serta melakukan suatu analisis data dari permasalahan untuk memperoleh suatu kesimpulan dengan tujuan untuk menggambarkan dan menganalisis secara sistematis terhadap suatu fakta yang sifatnya faktual.

Subyek yang dijadikan Penelitan ini adalah guru-guru yang ada di SD Negeri Kampung Sawah Kecamatan Bogor Utara Kota Bogor yaitu guru kelas I s.d VI berjumlah 9 orang guru kelas dan 3 guru mata pelajaran (guru Pendidikan Agama Islam 2 orang dan 1 orang guru Penjaskes). Penelitian ini akan dilaksanakan pada semester 2 tahun pelajaran 2017-2018, sebab pada awal semester 2 merupakan waktu yang tepat dalam memberikan dan melaksanakan tugas-tugas bagi guru untuk persiapan pada semester 1 tahun pembelajaran yang akan datang.

Penelitian Tindakan Sekolah ini dilaksanakan dalam dua siklus merupakan proses pengkajian melalui sistem yang berdaur ulang dari berbagai kegiatan pelatihan. Dalam setiap siklus terdiri dari 4 (empat) tahapan yaitu (1) perencanaan, (2) pelaksanaan, (3) pengamatan, dan (4) refleksi. Secara visual. Instrumen atau alat yang digunakan dalam peneltian tindakan sekolah ini adalah dengan menggunakan lembar observasi, angket, dan lembar kisi-kisi soal yang diadopsi dari panduan petunjuk pelaksanaan penilaian.

Pengolahan data dalam penelitian ini adalah sebagai berikut: 1. mengolah data yang terkumpul seperti data aktivitas guru sewaktu proses pembelajaran yaitu lembar observasi, data berupa angket yang diperoleh dari hasil jawaban guru, data lembar observasi pengamatan. 2. Menyeleksi data, Langkah ini dilakukan untuk mengetahui apakah data yang terkumpul dapat diolah atau tidak. 3 . Mengklarifikasikan dan mentabulasikan data. Langkah klarifikasi data dilakukan untuk mengelompokkan data sesuai dengan alternatif jawaban yang tertera dalam kuesioner, sedangkan langkah mentabulasikan data dilakukan untuk memperoleh gambaran mengenai jumlah frekuensi dan kecenderungannnya dalam kuesioner. 4. Menghitung Persentasi. Persentase digunakan untuk melihat besarnya persentase dari setiap alternatif jawaban pada setiap pertanyaan sehingga data yang diperoleh dapat dianalisa. 5. Mengumpulkan hasil penelitian setelah data dianalisis.

Berdasarkan data yang telah terkumpul, maka dilakukan analisis dan refleksi terhadap hasil dan proses tindakan yang telah dilakukan. Analisis dilakukan dengan beberapa acara. Untuk data hasil kemampuan guru menyusun LKS dianalisis dengan menggunakan deskriftif berupa rata-rata. Untuk data hasil observasi digunakan analisis deskriftif kualitatif, dan untuk data hasil dokumentasi digunakan untuk mengetahuigambaran kegiatan guru dalam kegiatan menyusun LKS.

Untuk keperluan refleksi dilakukan teknik matching atau perbandingan antara hasil tindakan dengan indikator kinerja yang telah ditetapkan. Selain itu juga dilakukan interprestasi hasil analisis dan semua data observasi secara cermat agar dapat ditentukan tindakan perbaikan yang tepat untuk perbaikan atau pengembangan tindakan berikutnya. Jika hasil analisis dan refleksi menunjukkan hasil tindakan lebih baik atau sama dengan indikator yang telah ditetapkan, maka penelitian ini dinilai berhasil. Jika hasilnya lebih jelek, maka penelitian tindakan ini ditetapkan belum berhasil, dan selanjutnya dilakukan perbaikan ulang dalam siklus kegiatan kedua dan seterus.

\section{HASIL DAN PEMBAHASAN}

Observasi awal dilakukan kepada guru-guru mengenai lembar kerja pada rencana pelaksanaan pembelajaran. Hasil observasi menunjukkan bahwa guru dalam penyusunan lembar kerja masih belum paham.. Berdasarkan hal tersebut maka dicoba menggunakan gugus sebagai wadah kegiatan guru dalam menyusun lembar kerja siswa pada guru-guru SD Negeri Kampung Sawah kecamatan Bogor Utara Kota Bogor. 
Proses penugasan, untuk mengetahui kemampuan awal guru dalam menyusun lembar kerja siswa. Hasil pengamatan awal digunakan acuan untuk mengetahui hasil setelah menggunakan gugus sebagai wadah kegiatan .

\section{Tindakan Siklus 1}

Siklus 1 dilaksanakan dalam 2 kali pertemuan yaitu pertemuan ke I dilaksanakan pada hari Sabtu tanggal 24 Februari 2018, sedangkan pertemuan ke II dilaksanakan pada hari Sabtu tanggal 3 Maret 2018.

a. Perencanaan Tindakan.

1)Sebelum menyusun rencana pengamatan, peneliti melaksanakan identifikasi masalah dan merencanakan langkah-langkah yang akan dilaksanakan pada siklus 1. 2). Setelah mengetahui masalah dan langkah-langkah yang akan dilakukan pada tindakan di siklus 1, peneliti kemudian membuat Rencana Pelaksanaan Pengamatan. 3). Menentukan kegiatan yang akan dijadikan materi bahasan pada penelitian. 4). Mengembangkan Rencana Pelaksanaan Penelitian.

\section{b. Pelaksanaan}

Pelaksanaan pada siklus 1, guru ditugaskan untuk membuat lembar kerja siswa.

\section{c. Observasi}

Lembar kerja siswa yang dibuat guru dikumpulkan dan diobservasi, berapa orang yang membuat dan berapa orang yang tidak membuat. Hasil pengamatan pada siklus 1 menunjukkan ada peningkatan dalam pembuatan lembar kerja siswa. Tetapi masih ada yang belum membuat.

\section{d. Refleksi}

Hasil obervasi lembar kerja yang dibuat guru kemudian dievaluasi, lembar kerja yang belum sempurna maka disempurnakan kembali, sampai pembuatan lembar kerja tersebut dapat semakin baik.

\section{Tindakan Siklus 2}

\section{a. Perencanaan Tindakan}

1) setelah melaksanakan pengamatan pada siklus 1 , peneliti melaksanakan identifikasi masalah dan merencanakan langkah-langkah yang akan dilaksanakan pada siklus 2. 2). Setelah mengetahui masalah dan langkah-langkah yang akan dilakukan pada tindakan di siklus 2, peneliti kemudian membuat Rencana Pelaksanaan Pengamatan. 3). Menentukan pokok bahasan yang akan dijadikan materi bahasan pada penelitian. Yaitu menyusun Lembar Kerja Siswa Ilmu Pengetahuan Alam 4). Mengembangkan Rencana Pelaksanaan Penelitian.

\section{b.Pelaksanaan}

Pelaksanaan pada siklus 2, guru ditugaskan untuk membuat lembar kerja siswa untuk materi selanjutnya.

\section{c.Observasi}

Lembar kerja siswa yang dibuat guru dikumpulkan dan diobservasi, berapa orang yang membuat dan berapa orang yang tidak membuat.
Hasil pengamatan pada siklus 2 menunjukkan ada peningkatan dalam pembuatan lembar kerja siswa. $82 \%$ guru membuat lembar kerja siswa

\section{d.Refleksi}

Hasil obervasi lembar kerja yang dibuat guru kemudian dievaluasi, lembar kerja yang belum sempurna maka disempurnakan kembali, sampai pembuatan lembar kerja tersebut dapat semakin baik.

Pada pra siklus, di observasi guru-guru yang membuat RPP dengan muatan Lembar Kerja Siswa. ada $25 \%$ guru yang dalam RPP nya termuat lembar kerja siswa. $75 \%$ orang guru tidak membuat lembar kerja. Sedangkan dalam grafiknya dapat terlihat pada gambar 1 .

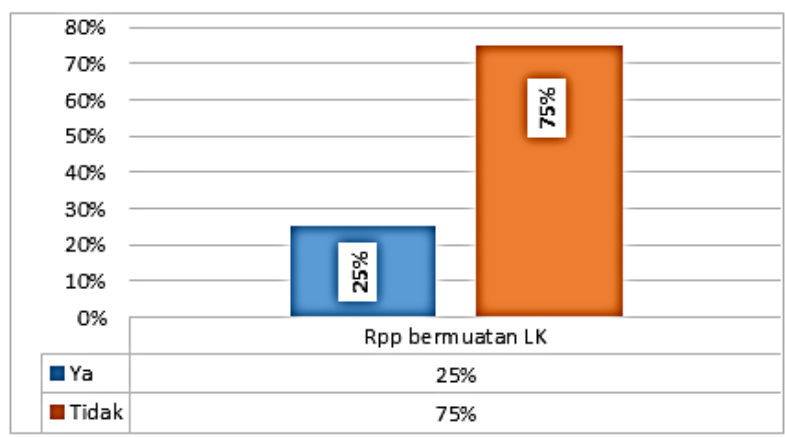

Gambar 1. Guru yang menyusun LKS pada pra siklus

Dari hasil awal tersebut maka dalam kegiatan gugus guru diberi tugas khusus membuat Lembar Kerja Siswa untuk melanjutkan LKS dari materi yang sudah dibuat. Pada siklus 1 hasil menunjukan terlihat ada peningkatan dalam pelaksanaan tugas walaupun hanya sedikit, yaitu menjadi $42 \%$ guru orang yang membuat LKS dan yang tidak melaksanakan menurun menjadi 58,33\%. terlihat pada gambar 2 sebagai berikut.

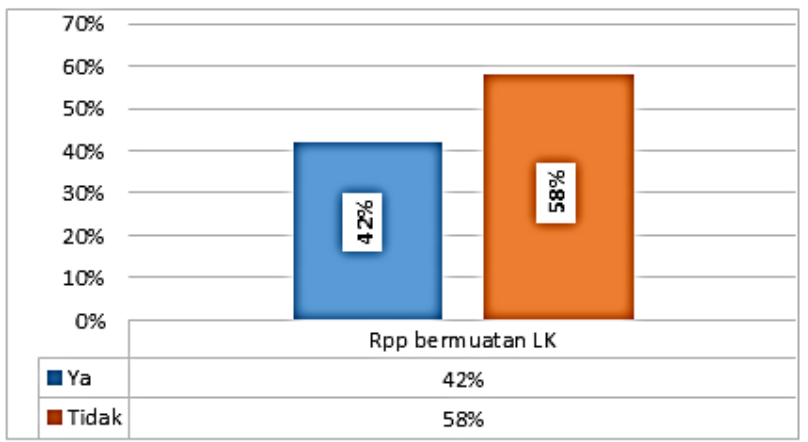

Gambar 2. Guru yang menyusun LKS pada siklus 1

Sedangkan pada penugasan ketiga guru ditugaskan untuk membuat LKS dari seluruh materi semester 2. Hasil penugasan dapat dilihat Hampir semua guru menyusun LKS dan menyelesaikan materi semester 2. yaitu $83 \%$ guru yang selesai seluruhnya menyusun dan $17 \%$ guru yang tidak selesai menyusun itu dapat terlihat juga pada gambar 3 


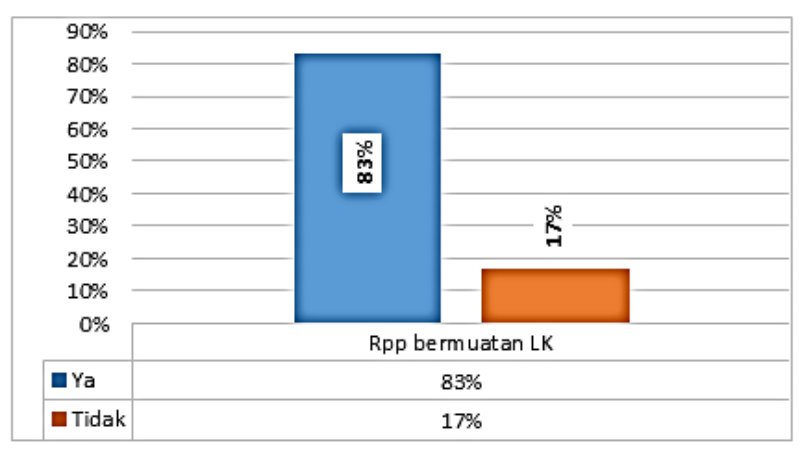

Gambar 2. Guru yang menyusun LKS pada siklus 1

Dalam penugasan terakhir masih ada guru yang tidak membuat Lembar Kerja dikarenakan guru tersebut sering sakit sehingga tidak sempat lagi untuk melaksanakan tugas pembuatan lembar kerja. Tetapi ada hal yang sangat menarik yaitu, guru mata pelajaran agama turut serta menyusun lembar kerja siswa tersebut dengan alasan karena lembar kerja siswa dapat membantu guru dalam proses pembelajaran dan pengumpulan nilai. Sehingga tanpa diberi tugaspun beliau menyusun sendiri lembar kerja pada mata pelajaran yang diampunya.

Hasil dari pengamatan pada pra siklus, siklus 1 dan 2 dapat dilihat Ada kenaikan yang cukup signifikan dalam penugasan menyusun LKS melalui workshop di Gugus sekolah. Dari $25 \%$ menjadi $42 \%$ pada siklus 1 dan naik lagi menjadi $83 \%$ pada siklus 2 . Hal itu membuktikan bahwa kegiatan di Gugus sekolah sangat membantu dalam meningkatkan kompetensi guru, dalam hal ini penyusunan LKS.

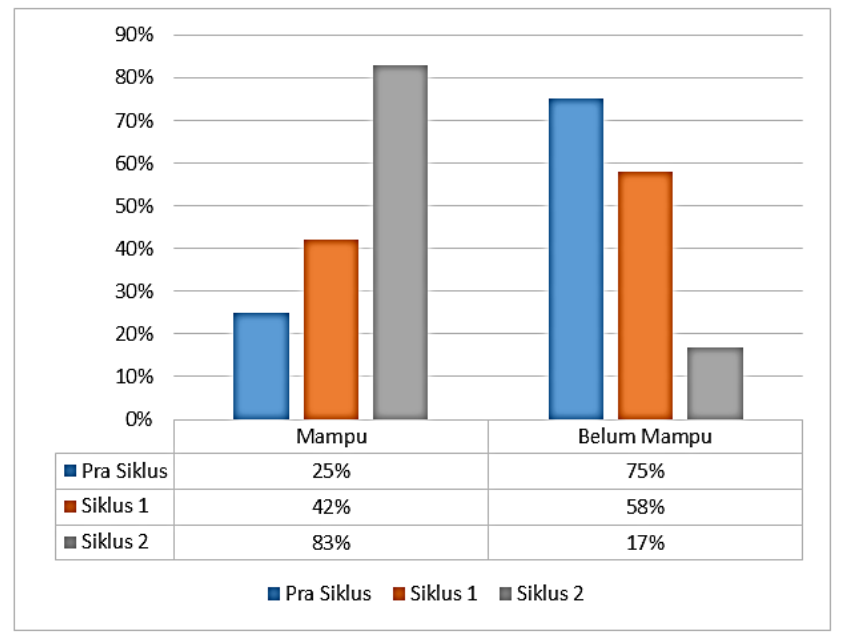

Gambar 3. Guru yang menyusun LKS pada kegiatan PTS

\section{SIMPULAN}

Berdasarkan hasil penelitian yang telah dilakukan terhadap guru di SD Negeri Kampung Sawah Kecamatan Bogor Utara Kota Bogor pada semester 2 tahun pelajaran 2017-2018, bahwa tingkat kompetensi guru dalam menyusun lembar kerja siswa melalu workshop di gugus sekolah yang dilakukan dengan dua siklus (siklus I dan siklus II) menunjukkan hasil yang sangat memuaskan. Dari uraian yang dipaparkan sebelumnya, maka dapat disimpulkan sebagai berikut: 1. Dengan melalui workshop di gugus telah dilakukan terhadap guru SD Negeri Kampung Sawah Kecamatan Bogor Utara Kota Bogor, sangat efektif untuk meningkatkan motivasi dan kompetensi guru dalam menyusun Lembar Kerja Siswa. 2. Proses peningkatan kemampuan guru dalam menyusun lembar kerja siswa melalui kegiatan pemberian materi menyusun lembar kerja siswa proses ini menghasilkan tingkat motivasi guru menjadi tinggi. 3. Adapun peningkatan kompetensi guru dalam penguasaan menyusun LKS sangat meningkat hal ini menunjukkan dari sebelum diadakan tindakan sampai dilaksanakan tindakan (siklus I dan siklus II) terdapat peningkatan yang sangat baik kemampuan guru dalam penguasaan menyusun LKS. Dengan demikian kegiatan Gugus sekolah dapat meningkatkan kompetensi guru dalam menyusun Lembar kerja siswa.

\section{REFERENSI}

[1] Y. Suchyadi and Nurjanah, 2018. "Relationship between Principal Supervision in Increasing the Job Satisfaction of Private Junior High School Teachers in East Bogor District," J. Humanit. Soc. Stud., vol. 02, no. 01, pp. 26-29.

[2] Y. Suchyadi, 2017. "Relationship between Work Motivation and Organizational Culture in Enhancing Professional Attitudes of Pakuan University Lecturers," vol. 01, no. 01.

[3] Payong, M. R. 2011. Sertifikasi profesi guru (konsep dasar, problematika dan implementasinya. Jakarta: PT. Indeks.

[4] Karsidi R. 2005. Profesionalisme guru dan peningkatan pendidikan di era otonomi daerah. Makalah disampaikan pada Seminar Nasional Pendidikan. Dewan Pendidikan Kabupaten. Wonogiri.

[5] Saud, Udin Saefudin. 2009. Pengembangan Profesi Guru, Penerbit : CV. Alfabeta, Banudng

[6] Boyatzis, R. E. 2008. Competencies in the 21st century. International Journal of Management Development, ISSN: 0262-1711, Vol. 27 (1).

[7] Mission, D. A. 2001. Training manual on competency based learning assesment. AGAMI Printing \& Publishing Co.

[8] Lynn, V. C.,\& Nixon, J. E. 1985. Physical education: teacher education, guidliness for sport pedagogy. New York: Jhon Wiley \& Sons. Inc.

[9] Trianto. 2009. MendesainModel Pembelajaran Pembelajaran Inovatif-Progresif. Jakarta: PT Fajar Interpratama mandiri

[10] Arsyad, Azhar. 2011. MediaPembelajaran. Jakarta: PT. Rajagrafindo Persada..

[11] Slameto.2003. Belajar dan Faktor-faktor yang mempengaruhi. Jakarta: Rineka Cipta.. 
[12] Bafadal, I. 2008. Seri Manajemen Peningkatan Mutu Pendidikan Berbasis Sekolah, Manajemen Perlengkapan Sekolah, Teori dan Aplikasi. Jakarta: PT Bumi Aksara.

[13] Brooks-Harris, Jeff E. 1999. Workshops: Designing and facilitating experiential learning. California : SAGE Publications. 